\title{
Polymorphisms of Cytochrome P450 2E1 Gene and Gastric Cancer Risk: A Case Control Study from West Bengal, India
}

\author{
Ghosh Sudakshina ${ }^{1}$, Ghosh Soumee ${ }^{1}$, Bankura Biswabandhu ${ }^{1}$, Saha Makhan Lal ${ }^{2}$, Panda Chinmay Kumar ${ }^{3}$, Chakraborty Subrata1 and Das Madhusudan ${ }^{1 *}$ \\ ${ }^{1}$ Department of Zoology, University of Calcutta, Kolkata, India \\ ${ }^{2}$ Department of Surgery, Institute of Post Graduate Medical Education and Research, Kolkata, India \\ ${ }^{3}$ Department of Oncogene Regulation and Viral Associated Human Cancer, Chittaranjan National Cancer Institute, Kolkata, India
}

*Corresponding author: Das M, Department of Zoology, University of Calcutta, 35 Ballygunge Circular Road, Kolkata-700019, West Bengal, India, Tel: +91-09831281756; Fax: +91-33-24614849; E-mail: madhuzoo@yahoo.com

Received date: April 3, 2017; Accepted date: May 5, 2017; Published date: May 13, 2017

Copyright: ( 2017 Ghosh, et al. This is an open-access article distributed under the terms of the Creative Commons Attribution License, which permits unrestricted use, distribution, and reproduction in any medium, provided the original author and source are credited.

\begin{abstract}
Background: Rsal/Pstl and Dral polymorphisms of cytochrome P450 2E1 (CYP2E1) gene are regarded as the most common polymorphisms associated with gastric cancer (GC). Very few data of these polymorphisms have been reported from India with regard to GC risk. We evaluated Rsal: -C1053T (rs2031920), Pstl: -G1295C (rs3813867) site in the 5' flanking region, Dral: T7668A (rs6413432) site in intron 6, -G71T rs6413420 and G4768A or V179I rs6413419 polymorphisms of CYP2E1 with GC risk in the population of West Bengal, India.
\end{abstract}

Methods: We enrolled 105 GC patients (cases) and corresponding sex, age and ethnicity matched normal 108 individuals (controls) for the study. Genotyping for rs6413419, rs6413420, rs6413432, rs2031920, rs3813867 of CYP2E1 was performed using DNA sequencing and RFLP analysis.

Results and conclusion: Our results suggest that the difference between genotype frequencies of rs3813867 and rs2031920, although not statistically significant but the allele frequencies of rs3813867 (OR=2.29, 95\% $\mathrm{Cl}=1.01-5.18, \mathrm{p}=0.042)$ and $\mathrm{rs} 2031920(\mathrm{OR}=2.29,95 \% \mathrm{Cl}=1.01-5.18, \mathrm{p}=0.042)$ showed significant difference between GC and control individuals. This when pooled with smoking augmented GC risk by nearly 4-fold. Therefore, a larger population is needed to be screened to confirm the association of these studied SNPs with GC in India.

Keywords Gastric cancer; Cytochrome P4502E1; SNPs

\section{Introduction}

Gastric cancer (GC) is one of the most common cancers of the gastrointestinal (GI) tract. It accounts for nearly $8 \%$ of the total cancer cases and results in $10 \%$ of the overall cancer related deaths. More than $70 \%$ of new cases of GC are reported to occur in the developing countries [1]. Although the exact mechanisms of gastric carcinogenesis are still unknown, yet it has been hypothesized to be caused by the interplay of both environmental and genetic factors which differs among different ethnic groups, gender, age and habitual behaviours [2-5]. Earlier epidemiological studies showed the role of smoking, drinking and $\mathrm{H}$ pylori infection towards the development of GC [6,7]. However, only a small section of the people exposed to these environmental factors develops GC in the long run, which is indicative of the fact that host genetic factors may also play critical role in gastric carcinogenesis. Polymorphisms of several genes associated with GC risk have been identified worldwide. Of them, cytochrome P4502E1 (CYP2E1) gene encoding the metabolizing enzyme CYP2E1 has been of much importance. It is responsible for the metabolic activation of various carcinogens, such as benzene, vinyl chloride and $\mathrm{N}$ dimethylnitrosamines and hence related to cancer threat [8-10]. The activity of this ethanol-inducible enzyme varies with several single nucleotide polymorphisms (SNPs) in the gene encoding this enzyme. For instance, RsaI/PstI polymorphisms, which are in complete linkage disequilibrium (LD), in the 5'-flanking promoter region of CYP2E1 are reported to affect its transcriptional activation [11]. However, the results are controversial. In contrast, the DraI polymorphisms have been found to be associated with only enhanced transcription [12]. RsaI/PstI and DraI polymorphisms are regarded as the most common and influential polymorphisms in CYP2E1 [12] and have been studied with various cancer risks [13-17]. But how the genetic variations of CYP2E1 can elevate the GC risk remains elusive. Moreover, to the best of our knowledge till date, very few data of this gene with regard to GC risk has been reported from India. Thus, our study was aimed to find out the association of CYP2E1 polymorphisms (rs6413419, rs6413420, rs6413432, rs2031920, rs3813867) with GC risk in the population of West Bengal, India.

\section{Subjects and Methods}

\section{Patients and control samples}

One hundred and five GC cases were recruited from the Department of Surgery, Institute of Post Graduate Medical Education and Research (IPGME and R), Kolkata, West Bengal, India from December 1, 2012 to April 30, 2015. All the individuals enrolled in our study were Bengali. Patients who were newly diagnosed with GC without any other chronic disease and histopathologically confirmed were included. According to histology, the gradations of tumour tissue samples were done using Lauren's classification [18]. One hundred and eight age, sex and ethnicity matched healthy control subjects who neither had cancer nor any familial history of neoplasms were selected 
from the same geographical region and socioeconomic status. Their non-cancer status was confirmed by medical examinations including radiographic examinations. Ethical approval for this study was given by the institutional ethics committee of Institute of Post Graduate Medical Education and Research (IPGME and R), Kolkata, West Bengal, India. A signed informed consent was taken from each of the participants. Each individual participating in the study was interviewed for their life style, socio-demographic characteristics, family history of cancer or any other chronic diseases, habitual behaviors like smoking, drinking and dietary habits and physical activity.

\section{Body mass index (BMI)}

Height and weight were measured in both patients and controls wearing light clothing and no shoes, to the nearest $0.1 \mathrm{~cm}$ and $0.1 \mathrm{Kg}$, respectively. BMI was calculated with the standard formula: BMI=Weight $(\mathrm{kg}) /$ Height $(\mathrm{m})^{2}$.

\section{Blood collection and DNA extraction}

Whole blood $(\sim 5 \mathrm{~mL})$ samples were taken from all subjects and collected in separate tubes (contain EDTA, 0.5 M). Genomic DNA was extracted using the DNA extraction kit (QIAamp Blood Kit, QIAGEN, Hilden, Germany) according to the manufacture's instruction.

\section{PCR analysis and direct sequencing}

Five SNPS (rs6413419, rs6413420, rs6413432, rs2031920, rs3813867) of CYP2E1 gene were amplified using specific primers by polymerase chain reaction (PCR). The primers used for each of the amplifications were described in Table 1. PCR amplification was done in a $30 \mu \mathrm{l}$ volume containing $100 \mathrm{ng}$ of DNA, $0.5 \mu \mathrm{M}$ of each primer, $0.2 \mathrm{mM}$ of deoxyribonucleotide triphosphate $\mathrm{mix}$, (Invitrogen Carlsbad, CA, USA), $1.5 \mathrm{mM}$ magnesium chloride, $1 \mathrm{x}$ buffer and 2.5 Unit Taq Polymerase (Invitrogen). PCR conditions were as follows: denaturation at $94^{\circ} \mathrm{C}$ for 3 min followed by 44 cycles of denaturation for $30 \mathrm{~s}$, annealing at $58^{\circ} \mathrm{C}-60^{\circ} \mathrm{C}$ for $30 \mathrm{~s}$, extension at $72^{\circ} \mathrm{C}$ for $45 \mathrm{~s}$ and final extension at $72^{\circ} \mathrm{C}$ for $5 \mathrm{~min}$. PCR products were subjected to direct DNA sequencing. For rs6413419 and rs6413420, forward and reverse strand sequencing was carried out using the big dye terminator kit (Applied Biosystems, Foster City, CA, USA) on an automated DNA capillary sequencer (Model 3700; Applied Biosystems).

\begin{tabular}{|l|l|l|l|}
\hline SNPs (rs number) & $\begin{array}{l}\text { Sequence (5' } \mathbf{3}^{\prime} \text { ) } \\
\text { F: } \text { Forward } \\
\text { R: } \text { Reverse }\end{array}$ & $\begin{array}{l}\text { Digestion pieces } \\
\text { (restriction enzyme) }\end{array}$ & Amplicon Length \\
\hline rs6413419 & $\begin{array}{l}\text { F: CTCAAACAGGTTCAGACATTCAC } \\
\text { R: GTTGATGACTGATGAAGAGGAAG }\end{array}$ & $347 \mathrm{bp}$ \\
\hline rs6413420 & $\begin{array}{l}\text { F: AACATGTTCCTGGATGTGTTTG } \\
\text { R: ATGATGGGAAGCGGGAAAG }\end{array}$ & $421 \mathrm{bp}$ \\
\hline rs6413432 & $\begin{array}{l}\text { F: AGGCTCGTCAGTTCCTGAAAG } \\
\text { R: TTCCATGGTTCCCTAGTGC }\end{array}$ & $\begin{array}{l}\text { Allele T: } 867 \\
\text { Allele A:559, } 308 \text { (Dra1) }\end{array}$ & $867 \mathrm{bp}$ \\
\hline $\begin{array}{l}\text { rs3813867 } \\
\text { rs2031920 }\end{array}$ & $\begin{array}{l}\text { F:CCAGTCGAGTCTACATTGTCA } \\
\text { R:TTCATTCTGTCTTCTAACTGG }\end{array}$ & $\begin{array}{l}\text { Allele C: } 413 \\
\text { Allele G: } 114,299 \text { (Pstl) } \\
\text { Allele T: } 413 \\
\text { Allele C: } 353,60 \text { (Rsal) }\end{array}$ & $413 \mathrm{bp}$ \\
\hline
\end{tabular}

Table 1: Primer sequences and restriction enzymes used for detection of CYP2E1 gene polymorphisms.

\section{RFLP analysis}

PCR amplified products were digested using DraI (rs6413432), PstI (rs3813867) and RsaI (rs2031920) enzymes according to the manufacturer's instructions (New England Biolabs Inc.). Fragments were separated and analyzed by $2.5 \%$ agarose gel electrophoresis. Samples of five randomly selected subjects were analyzed twice by direct DNA sequencing to assess the consistency of the genotyping protocol.

\section{Statistical analysis}

For each SNP, the genotypic data were analyzed by using multivariate logistic regression model. The demographic variables and life style habits (smoking and alcohol consumption) between cases and controls were compared by t-tests (for continues variables) and chisquare tests (for categorical variables). Hardy-Weinberg equilibrium of each SNP was examined using a $\chi^{2}$ test. Next, unconditional logistic regression model was used to evaluate the risk of GC with regard to smoking status, alcohol consumption and BMI. All the tests were done using GraphPad InStat software (GraphPad InStat software, San Diego,
CA) and SNPassoc version 1.81 software (Catalan Institute of Oncology, Barcelona, Spain). Linkage disequilibrium (LD) pattern was analyzed using Haploview 4.2.

\section{Results}

\section{Characteristics of study participants}

The study was performed with 105 GC patients (78\% males and $22 \%$ females) having mean age of $55.43 \pm 10.86$ years (range $22-80$ years). There was a male predominance of GC frequency compared to females. Based on the anatomical location, $98 \%$ of the patients had non-cardia and only $2 \%$ had cardia type of GC. Histology revealed the sample population to be of $49 \%$ intestinal, 23\% diffuse and $28 \%$ indeterminate type. Smoking $(\mathrm{OR}=2.45,95 \% \mathrm{CI}=1.41-4.26, \mathrm{p}=0.001)$ and alcohol consumption ( $\mathrm{OR}=2.77,95 \% \mathrm{CI}=1.52-5.06, \mathrm{p}=0.001)$ varied significantly between cases and controls where both were found to independently increase the risk of GC. Only $20 \%$ of the cases were H. pylori positive and familial cluster for GC occurrence was not observed in our study Table 2. 
Citation: Ghosh S, Ghosh S, Bankura B, Saha ML, Panda CK, et al. (2017) Polymorphisms of Cytochrome P450 2E1 Gene and Gastric Cancer Risk: A Case Control Study from West Bengal, India. J Clin Med Genomics 5: 148. doi:10.4172/2472-128X.1000148

Page 3 of 6

\begin{tabular}{|c|c|c|c|c|}
\hline Characteristics & Control $(n=108)$ & Case $(n=105)$ & Odds ratio $(95 \% \mathrm{Cl})$ & $p$ value \\
\hline${ }^{*}$ Age (years \pm SD) & $53.64 \pm 7.88$ & $55.43 \pm 10.86$ & & 0.169 \\
\hline \multicolumn{5}{|l|}{ Sex } \\
\hline Male & 89 & 82 & & \\
\hline Female & 19 & 23 & & 0.429 \\
\hline${ }^{*} \mathrm{BMI}\left(\mathbf{k g} / \mathbf{m}^{2}\right)$ & $23.28 \pm 1.97$ & $20.55 \pm 2.75$ & & $<0.001$ \\
\hline \multicolumn{5}{|l|}{ Anatomical location } \\
\hline Cardia & - & 3 & & \\
\hline Non-cardia & - & 102 & & \\
\hline \multicolumn{5}{|c|}{ Histological subtypes of tumour } \\
\hline Intestinal & - & 52 & & \\
\hline Diffuse & - & 24 & & \\
\hline Indeterminate & - & 29 & & \\
\hline \multicolumn{5}{|c|}{ Alcohol consumption } \\
\hline No & 85 & 60 & & \\
\hline Ever & 23 & 45 & $2.77(1.52-5.06)$ & 0.001 \\
\hline \multicolumn{5}{|c|}{ Cigarette/bidi smoking } \\
\hline No & 66 & 41 & & \\
\hline Ever & 42 & 64 & $2.45(1.41-4.26)$ & 0.001 \\
\hline
\end{tabular}

Table 2: Clinical characteristics of gastric cancer patients and controls, ${ }^{\star}$ At diagnosis.

Out of the 5 SNPs studied, rs3813867 and rs2031920 were found to be strongly in LD Figure 1, as has been reported in other studies of the world population.

There were no significant differences between GC and controls in the distribution of either allelic or genotype frequencies of rs6413419, rs6413420 and rs6413432 Table 3.

However, only the allele frequencies of $\mathrm{rs} 3813867$ (PstI) (OR=2.29, 95\% $\mathrm{CI}=1.01-5.18, \mathrm{p}=0.042)$ and $\mathrm{rs} 2031920$ (RsaI) (OR=2.29, 95\% $\mathrm{CI}=1.01-5.18, \mathrm{p}=0.042)$ showed significant difference between $\mathrm{GC}$ and control individuals Table 3 and Figure 2.

A stratification analysis was conducted to evaluate the effects of interaction of PstI/RsaI with the risk of GC according to smoking status, alcohol consumption status and BMI. The difference between genotype frequencies of rs3813867 and rs2031920, although not statistically significant, yet individuals having $\mathrm{C}$ and $\mathrm{T}$ alleles respectively who were smokers had nearly 4 -fold risk of GC $(\mathrm{OR}=3.98$, 95\% CI=1.07-14.73) Table 4.

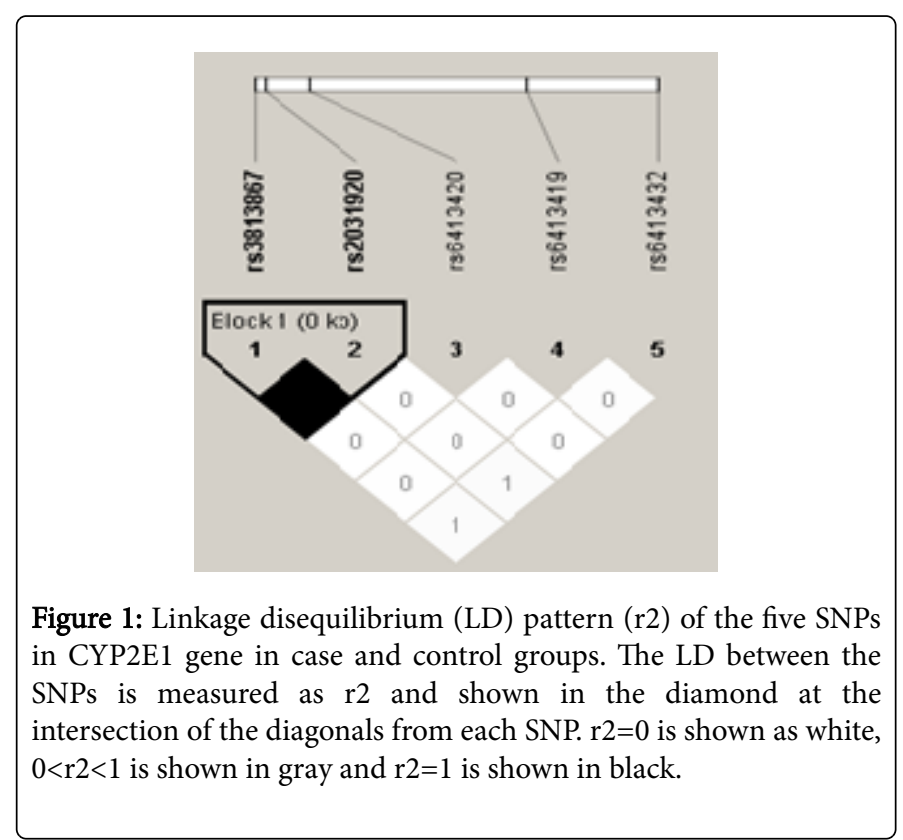


Citation: Ghosh S, Ghosh S, Bankura B, Saha ML, Panda CK, et al. (2017) Polymorphisms of Cytochrome P450 2E1 Gene and Gastric Cancer Risk: A Case Control Study from West Bengal, India. J Clin Med Genomics 5: 148. doi:10.4172/2472-128X.1000148

Page 4 of 6

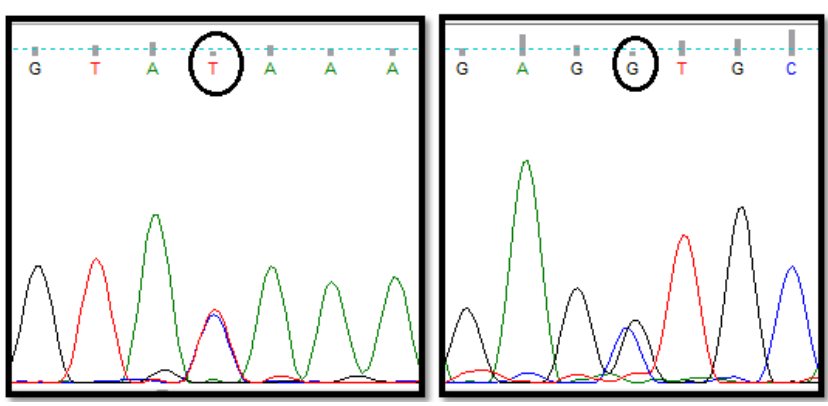

Figure 2: Chromatogram showing the RsaI (a) and PstI (b) heterozygotes

\begin{tabular}{|c|c|c|c|c|}
\hline Genotype & $\begin{array}{l}\text { Controls } \\
(n-108) n(\%)\end{array}$ & $\begin{array}{l}\text { Cases } \\
(\mathrm{n}-105) \quad \mathrm{n} \\
(\%)\end{array}$ & $\mathrm{OR}^{*}(95 \% \mathrm{Cl})$ & $p$-value \\
\hline $\begin{array}{l}\text { CYP2E1 } \\
\text { rs6413419 } \\
\text { GG } \\
\text { GA } \\
\text { AA } \\
\text { G allele } \\
\text { A allele }\end{array}$ & $\begin{array}{l}106(98.1) \\
2(1.9) \\
0(0) \\
99 \% \\
1 \%\end{array}$ & $\begin{array}{l}102(97.1) \\
3(2.9) \\
0(0) \\
99 \% \\
1 \%\end{array}$ & $\begin{array}{l}1.00 \\
1.56[0.26-9.52] \\
1.00 \\
1.00[0.15-6.75]\end{array}$ & $\begin{array}{l}0.628 \\
1.00\end{array}$ \\
\hline $\begin{array}{l}\text { CYP2E1 } \\
\text { rs6413420 } \\
\text { GG }\end{array}$ & $\begin{array}{l}102(94.4) \\
6(5.6)\end{array}$ & $\begin{array}{l}97(92.4) \\
8(7.6)\end{array}$ & $\begin{array}{l}1.00 \\
1.40[0.47-4.19]\end{array}$ & $\begin{array}{l}0.741 \\
0.73\end{array}$ \\
\hline
\end{tabular}

\begin{tabular}{|c|c|c|c|c|c|c|c|c|}
\hline & Exposure & Status & Genotypes & Control (n-108) & $\begin{array}{l}\text { Case } \\
(n-105)\end{array}$ & OR $(95 \%$ Cl)* & & $P$ value \\
\hline \multirow[t]{7}{*}{ rs3813867(Pstl) } & Smoking & Non-smoker & $\begin{array}{l}\mathrm{GG} \\
\mathrm{GC}\end{array}$ & $\begin{array}{l}60 \\
6\end{array}$ & $\begin{array}{l}38 \\
3\end{array}$ & $\begin{array}{l}\text { Reference: } \\
(0.19-3.35)\end{array}$ & 0.79 & 0.748 \\
\hline & & Smoker & $\begin{array}{l}\mathrm{GG} \\
\mathrm{GC}\end{array}$ & $\begin{array}{l}39 \\
3\end{array}$ & $\begin{array}{l}49 \\
15\end{array}$ & $\begin{array}{l}\text { Reference: } \\
(1.07-14.73)\end{array}$ & 3.98 & 0.019 \\
\hline & Alcohol & Non-alcoholic & $\begin{array}{l}\text { GG } \\
\text { GC }\end{array}$ & $\begin{array}{l}80 \\
5\end{array}$ & $\begin{array}{l}59 \\
3\end{array}$ & \multicolumn{2}{|l|}{$\begin{array}{l}\text { Reference: } \\
0.86(0.20-3.76)\end{array}$} & 0.844 \\
\hline & & Alcoholic & $\begin{array}{l}\mathrm{GG} \\
\mathrm{GC}\end{array}$ & $\begin{array}{l}19 \\
4\end{array}$ & $\begin{array}{l}28 \\
15\end{array}$ & $\begin{array}{l}\text { Reference: } \\
(0.73-8.86)\end{array}$ & 2.54 & 0.135 \\
\hline & \multirow[t]{2}{*}{ Smoking+Alcohol } & $\begin{array}{l}\text { Both non-smoker and } \\
\text { non-alcoholic }\end{array}$ & $\begin{array}{l}\text { GG } \\
\mathrm{GC}\end{array}$ & $\begin{array}{l}6 \\
24\end{array}$ & $\begin{array}{l}35 \\
2\end{array}$ & $\begin{array}{l}\text { Reference: } \\
(0.25-13.55)\end{array}$ & 1.83 & 0.549 \\
\hline & & $\begin{array}{l}\text { Both smoker and } \\
\text { alcoholic }\end{array}$ & $\begin{array}{l}\text { GG } \\
\text { GC }\end{array}$ & $\begin{array}{l}19 \\
4\end{array}$ & $\begin{array}{l}25 \\
11\end{array}$ & $\begin{array}{l}\text { Reference: } \\
(0.58-7.60)\end{array}$ & 2.09 & 0.257 \\
\hline & $\mathrm{BMI}$ & $<22$ & $\begin{array}{l}\text { GG } \\
\text { GC }\end{array}$ & $\begin{array}{l}23 \\
4\end{array}$ & $\begin{array}{l}53 \\
14\end{array}$ & Reference: & & 0.587 \\
\hline \multirow[t]{4}{*}{ rs2031920 Rsal } & Smoking & Non-smoker & $\begin{array}{l}\mathrm{CC} \\
\mathrm{CT}\end{array}$ & $\begin{array}{l}6 \\
60\end{array}$ & $\begin{array}{l}38 \\
3\end{array}$ & $\begin{array}{l}\text { Reference: } \\
(0.19-3.35)\end{array}$ & 0.79 & 0.748 \\
\hline & & Smoker & $\begin{array}{l}\mathrm{CC} \\
\mathrm{CT}\end{array}$ & $\begin{array}{l}39 \\
3\end{array}$ & $\begin{array}{l}49 \\
15\end{array}$ & $\begin{array}{l}\text { Reference: } \\
(1.07-14.73)\end{array}$ & 3.98 & 0.019 \\
\hline & Alcohol & Non-alcoholic & $\begin{array}{l}\mathrm{CC} \\
\mathrm{CT}\end{array}$ & $\begin{array}{l}80 \\
5\end{array}$ & $\begin{array}{l}59 \\
3\end{array}$ & $\begin{array}{l}\text { Reference: } \\
(0.20-3.76)\end{array}$ & 0.86 & 0.844 \\
\hline & & Alcoholic & $\begin{array}{l}\mathrm{CC} \\
\mathrm{CT}\end{array}$ & $\begin{array}{l}19 \\
4\end{array}$ & $\begin{array}{l}28 \\
15\end{array}$ & $\begin{array}{l}\text { Reference: } \\
(0.73-8.86)\end{array}$ & 2.54 & 0.135 \\
\hline
\end{tabular}

\begin{tabular}{|l|l|l|l|l|}
\hline GT & $0(0)$ & $0(0)$ & - & \\
TT & $97 \%$ & $96 \%$ & 1.00 & \\
G allele & $3 \%$ & $4 \%$ & $1.40[0.49-4.01]$ & \\
T allele & & & & \\
\hline CYP2E1CYP2 & & & & \\
E1 & $78(72.2)$ & $72(68.5)$ & 1 & \\
rs6413432 & $30(27.8)$ & $32(30.5)$ & $1.16[0.64-2.09]$ & \\
TT & $0(0)$ & $1(1)$ & -- & 0.743 \\
TA & $78(72.2)$ & $72(68.5)$ & 1 & 0.602 \\
AA & $30(27.8)$ & $33(31.5)$ & $1.27[0.71-2.38]$ & 0.436 \\
TT & $87 \%$ & $84 \%$ & 1 & \\
TA+AA & $13 \%$ & $16 \%$ & $1.30[0.74-2.29]$ & \\
T allele & & & & \\
A allele & & & & \\
\hline CYP2E1 & & $87(82.8)$ & 1.00 & \\
rs3813867 & $99(91.6)$ & $18(17.2)$ & $2.28[0.97-5.33]$ & 0.053 \\
GG & $9(8.4)$ & $0(0)$ & - & 0.042 \\
GC & $0(0)$ & $91 \%$ & 1.00 & \\
CC & $96 \%$ & $9 \%$ & $2.29[1.01-5.18]$ & \\
G allele & $4 \%$ & & & \\
C allele & & & & \\
\hline CYP2E1 & & & & \\
rs2031920 & $99(91.6)$ & $87(82.8)$ & 1.00 & \\
CC & $9(8.4)$ & $18(17.2)$ & $2.28[0.97-5.33]$ & 0.053 \\
CT & $0(0)$ & $0(0)$ & -- & 0.042 \\
TT & $96 \%$ & $91 \%$ & $2.29[1.01-5.18]$ & \\
C allele & $4 \%$ & $9 \%$ & & \\
T allele & & & & \\
\hline
\end{tabular}

Table 3: Genotype and allele frequencies of CYP2E1 and association with gastric cancer risk, ${ }^{*}$ Odds ratio were adjusted for age, sex, BMI, alcohol and smoking status. 
Page 5 of 6

\begin{tabular}{|l|l|l|l|l|l|l|l|}
\hline & Smoking+Alcohol & $\begin{array}{l}\text { Both non-smoker and } \\
\text { non-alcoholic }\end{array}$ & $\begin{array}{l}\text { CC } \\
\text { CT }\end{array}$ & $\begin{array}{l}64 \\
2\end{array}$ & $\begin{array}{l}35 \\
2\end{array}$ & $\begin{array}{l}\text { Reference: } \\
(0.25-13.55)\end{array}$ & $\begin{array}{l}1.83 \\
0.549\end{array}$ \\
\hline & $\begin{array}{l}\text { Both smoker and } \\
\text { alcoholic }\end{array}$ & $\begin{array}{l}\text { CC } \\
\text { CT }\end{array}$ & $\begin{array}{l}19 \\
4\end{array}$ & $\begin{array}{l}25 \\
11\end{array}$ & $\begin{array}{l}\text { Reference: } \\
(0.58-7.60)\end{array}$ \\
\hline & BMI & $\begin{array}{l}\text { CC } \\
\text { CT }\end{array}$ & $\begin{array}{l}23 \\
4\end{array}$ & $\begin{array}{l}53 \\
14\end{array}$ & $\begin{array}{l}\text { Reference: } \\
(0.22-14.79)\end{array}$ \\
\hline
\end{tabular}

Table 4: Interaction between CYP2E1 rs3813867, rs2031920 polymorphisms and smoking and alcohol consumption in gastric cancer, ${ }^{*}$ Odds ratio were adjusted for age, sex, BMI, alcohol and smoking status.

\section{Discussion}

The genes that encode the CYP family of enzymes are highly polymorphic and thus lead to inter individual variation in enzyme activity. The activation of various carcinogens like polycyclic aromatic hydrocarbons, nitrosamines and heterocyclic amines involves the active role of these enzymes. An increased risk of GC associated with CYP2E1 polymorphisms that can modify the effects of environmental factors have now been confirmed in many populations throughout the world i.e. Korean [19,20], Chinese [21] and Taiwanese [22]. This enzyme also reduces oxygen molecule to highly active form, which is carcinogenic, and may lead to cancer development [23]. Previous research showed that CYP2E1 gene polymorphisms may be a cause of development of GC [24-29]. The most widely studied SNPs of CYP2E1 are RsaI: -C1053T (rs2031920), PstI -G1295C (rs3813867) site in the 5' flanking region, DraI: T7668A (rs6413432) site in intron 6, -G $71 \mathrm{~T}$ rs6413420 and G4768A or V179I rs6413419 [30-33]. The present study was aimed to find out the association between these five most studied SNPs of CYP2E1 and GC incidence in the population of West Bengal, India. We screened 105 GC patients and 108 normal individuals for the study. RsaI/PstI and DraI polymorphisms are regarded as the most frequent and powerful polymorphisms in CYP2E1 that are considered to enhance transcription [12]. Our results suggest that the difference between genotype frequencies of rs 3813867 and rs2031920, although not statistically significant but the allele frequencies of $\mathrm{rs} 3813867(\mathrm{OR}=2.29,95 \% \mathrm{CI}=1.01-5.18, \mathrm{p}=0.042)$ and rs2031920 (OR=2.29, 95\% CI=1.01-5.18, $\mathrm{p}=0.042)$ showed significant difference between GC and control individuals. It was also found to interact with smoking thereby increasing the risk of GC by nearly 4fold. However, a study in India from the north eastern state of Mizoram found no association of RsaI polymorphism with GC risk [33]. We found no significant association of SNPs rs6413419 and rs6413420 with GC in our study. Similar results were also observed for oral cancer susceptibility in South Indians [12]. Interestingly, in their study, V179I rs6413419 locus was monomorphic which was different from our finding where we obtained heterozygotes in both case and control population. In another study, CYP2E1 polymorphism and a history of habitual drinking were shown to increase the risk of intestinal-type GC [34]. In India, the incidence of GC varies across different registries. A higher incidence has been reported in the South compared to the North. The highest rate of GC cases is reported from the North Eastern state of Mizoram [35]. But the same being comparatively low in the state of West Bengal, the sample size of this study was limited. Therefore, a larger population is needed to be screened to validate these findings.

\section{Conclusion}

We conducted the first study of association between CYP2E1 polymorphisms and the risk of GC from West Bengal, India. Our results suggest that the difference between genotype frequencies of rs3813867 and rs2031920, although not statistically significant but the allele frequencies of rs3813867 and rs2031920 showed significant difference between GC and control individuals. This when combined with smoking increased the risk of GC by nearly 4 -fold. However, study with larger sample may contribute to a better understanding towards the association of GC with the studied SNPs.

\section{Conflict of Interest}

We have no conflict of interest to declare.

\section{Acknowledgement}

We are indebted to the volunteers who participated in this study. This work was supported by CSIR fellowship from the Council of Scientific and Industrial Research (CSIR), Government of India [09/028(0891)/2012-EMR-1 DATE-20.12.2012] to Sudakshina Ghosh and the DBT-Twinning Project on Gastric Cancer [BT/360/NE/TBP/ 2012 dated-25.03.2013] sponsored by the Department of Biotechnology (DBT), New Delhi, Govt. of India.

\section{References}

1. Jemal A, Bray F, Center MM, Ferlay J, Ward E (2011) Global cancer statistics. CA Cancer J Clin 61: 69-90.

2. Hamilton JP, Meltzer S (2006) A review of the genomics of gastric cancer. Clin Gastroenterol Hepatol 4: 416-425.

3. Gianfagna F, De Feo E, van Duijn CM, Ricciardi G, Boccia S (2008) A systematic review of meta-analyses on gene polymorphisms and gastric cancer risk. Curr Genomics 9: 361-374.

4. Saeki N, Ono H, Sakamoto H, Yoshida T (2013) Genetic factors related to gastric cancer susceptibility identified using a genome-wide association study. Cancer Sci 104: 1-8.

5. Yoshida T, Ono H, Kuchiba A, Saeki N, Sakamoto H (2010) Genomewide germ line analyses on cancer susceptibility and GeMDBJ database: Gastric cancer as an example. Cancer Sci 101: 1582-1589.

6. Moy KA, Fan Y, Wang R, Gao YT, Yu MC (2010) Alcohol and tobacco use in relation to gastric cancer: A prospective study of men in Shanghai, China. Cancer Epidemiol Biomarkers Prev 19: 2287-2297.

7. Rathbone M, Rathbone B (2011) Helicobacter pylori and gastric cancer. Recent Results Cancer Res 185: 83-97.

8. Guengerich FP, Kim DH, Iwasaki M (1991) Role of human cytochrome P-450 IIE1 in the oxidation of many low molecular weight cancer suspects. Chem Res Toxicol 4: 168-179. 
Citation: Ghosh S, Ghosh S, Bankura B, Saha ML, Panda CK, et al. (2017) Polymorphisms of Cytochrome P450 2E1 Gene and Gastric Cancer Risk: A Case Control Study from West Bengal, India. J Clin Med Genomics 5: 148. doi:10.4172/2472-128X.1000148

Page 6 of 6

9. Bellec G, Dreano Y, Lozach P, Menez JF, Berthou F (1996) Cytochrome P450 metabolic dealkylation of nine N-nitrosodialkylamines by human liver microsomes. Carcinogenesis 17: 2029-2034.

10. Schuller HM (2007) Nitrosamines as nicotinic receptor ligands. Life Sci 80: 2274-2280.

11. Hayashi S, Watanabe J, Kawajiri K (1991) Genetic polymorphisms in the 59- flanking region change transcriptional regulation of the human cytochrome P450IIE1 gene. J Biochem 110: 559-565.

12. Uematsu F, Ikawa S, Kikuchi H (1994) Restriction fragment length polymorphism of the human CYP2E1 (cytochrome P450IIE1) gene and susceptibility to lung cancer: Possible relevance to low smoking exposure. Pharmacogenetics 4: 5863.

13. Tang K, Li Y, Zhang, Gu Y, Xiong Y, et al. (2010) The PstI/RsaI and DraI polymorphisms of CYP2E1 and head and neck cancer risk: A metaanalysis based on 21 case-control studies. BMC Cancer 10: 575-582.

14. Su X, Bin B, Cui H, Ran M (2011) Cytochrome P450 2E1 RsaI/PstI and DraI polymorphisms are risk factors for lung cancer in Mongolian and Han population in inner Mongolia. Chin J Cancer Res 23: 107-111.

15. Feng J, Pan X, Chen Z, Xu H, Ei Rifai Z, et al. (2012) Functional Pst1/Rsa1 polymorphismin CYP2E1 is associated with the development, progression and poor outcome of gastric cancer. PLoS ONE 7: e44478.

16. Guo Y, Zhou S, Liu F, Zhang B (2015) CYP2E1 RsaI/PstI polymorphisms contributed to oral cancer susceptibility: A meta-analysis. Int J Clin Exp Pathol 8: 14685-14692.

17. Zhuo X, Song J, Liao J, Zhou W, Ye H, et al. (2016) Does CYP2E1 RsaI/ PstI polymorphism confer head and neck carcinoma susceptibility? A meta-analysis based on 43 studies. Medicine (Baltimore) 95: e5156.

18. Lauren P (1965) The two histological main types of gastric carcinoma: diffuse and so-called intestinal-type carcinoma. An attempt at a histoclinical classification. Acta Pathol Microbiol Scand 64: 31-49.

19. Park JY, Harris D (2003) Construction and assessment of models of CYP2E1: predictions of metabolism from docking, molecular dynamics, and density functional theoretical calculations. J Med Chem 46: $1645-1660$.

20. Nan HM, Song YJ, Yun HY, Park JS, Kim H (2005) Effects of dietary intake and genetic factors on hypermethylation of the hMLH1 gene promoter in gastric cancer. World J Gastroenterol 11: 3834-3841.

21. Zhou GW, Hu J, Li Q (2010) CYP2E1 PstI/RsaI polymorphism and colorectal cancer risk: A meta-analysis. World J Gastroenterol 16: 2949-2953.

22. Wu D, Cederbaum AI (2003) Role of p38 MAPK in CYP2E1-dependent Arachidonic Acid Toxicity. J Biol Chem 278: 1115-1124.

23. Guengerich FP, Kim DH, Iwasaki M (1991) Role of human cytochrome P-450IIE1 in the oxidation of many low molecular weight cancer suspects. Chem Res Toxicol 4: 68-79.
24. Klinchid J, Chewaskulyoung B, Saeteng S, Lertprasertsuke N, Kasinrerk W, et al. (2009) Effect of combined genetic polymorphisms on lung cancer risk in northern Thai women. Cancer Genet Cytogenet 195: 143-149.

25. Hata S, Miki Y, Fujishima F, Sato R, Okaue A, et al. (2010) Cytochrome $3 \mathrm{~A}$ and $2 \mathrm{E} 1$ in human liver tissue: Individual variations among normal Japanese subjects. Life Sci 86: 393-401.

26. Wang Y, Yang H, Li L (2010) Association between CYP2E1 genetic polymorphisms and lung cancer risk: A meta-analysis. Eur J Cancer 46: 758-764.

27. Ye X, Peng T, Liu T, et al. (2010) Association between aldehyde dehydrogenase-2/cytochrome P450 2E1 genetic polymorphism and habit of alcohol drinking and the susceptibility of hepatocellular carcinoma. Wei Sheng Yan Jiu 39: 42-45.

28. Balaji L, Balaji K, Bhaskar L (2011) Genetic Polymorphisms of the CYP2E1 Gene do not contribute to oral cancer susceptibility in South Indians. Asian Pacific J Cancer Prev 12: 1523-1527.

29. Sameer AS, Nissar S, Qadri Q, Alam S, Baba SM, et al. (2011) Role of CYP2E1 genotypes in susceptibility to colorectal cancer in the Kashmiri population. Hum Genomics 5: 530-537.

30. Liu Y, Meng XW, Zhou LY, Zhang PY, Sun X, et al. (2009) Genetic polymorphism and mRNA levels of cytochrome P450IIE1 and glutathione S-transferase P1 in patients with alcoholic liver disease in different nationalities. Hepatobiliary Pancreat Dis Int 8: 162-167.

31. Watanabe J, Hayashi S, Kawajiri K (1994) Different regulation and expression of the human CYP2E1 gene due to the RsaI polymorphism in the 50-flanking region. J Biochem 116: 321-326.

32. Cai L, Yu SZ, Zuo-Feng, Zhang ZF (2001) Cytochrome P450 2E1 genetic polymorphism and gastric cancer in Changle, Fujian Province. World J Gastroenterol 7: 792-795.

33. Malakar M, Devi KR, Phukan RK, Kaur T, Deka M, et al. (2014) CYP2E1 genetic polymorphism with dietary, tobacco, alcohol habits, H. pylori infection status and susceptibility to stomach cancer in Mizoram, India. Asian Pac J Cancer Prev 15: 8815-8822.

34. Suzuki S, Muroishi Y, Nakanishi I, Oda Y (2004) Relationship between genetic polymorphisms of drug-metabolizing enzymes (CYP1A1, CYP2E1, GSTM1 and NAT2), drinking habits, histological subtypes and p53 gene point mutations in Japanese patients with gastric cancer. J Gastroenterol 39: 220-230.

35. Sharma A, Radhakrishnan V (2011) Gastric cancer in India. Indian J Med Paediatr Oncol 32: 12-16. 